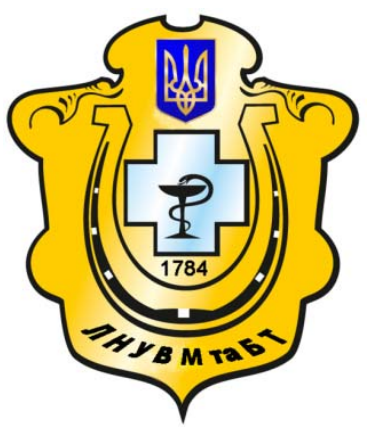

Науковий вісник Львівського національного університету ветеринарної медицини та біотехнологій імені С.3. Гжицького

Scientific Messenger of Lviv National University of Veterinary Medicine and Biotechnologies named after S.Z. Gzhytskyj

doi:10.15421/nvlvet6825

ISSN 2413-5550 print

ISSN 2518-1327 online

$\underline{\text { http://nvlvet.com.ua/ }}$

УДК 613.292:664.38:637.1:634.771

\title{
Дослідження впливу порошку з бананів на показники якості желейної продукції
}

\author{
М.С. Черниш, О.В. Нєміріч \\ margarita.chernysh@gmail.com, avnemirich@mail.ru \\ Національний університет харчових технологій, \\ вул. Володимирська, 68, м. Київ, 01601, Україна
}

\begin{abstract}
У статті проаналізовано сучасний стан виробництва і споживання десертів із желейної продукції та встановлено, що найбільшу популярність мають желе з натуральних інгредієнтів без иукру. Найбільш популярними вони є серед дітей. Перспективним напрямком збагачення желейної продукиії є використання порошків (представляють собою дрібнодисперсну порошкоподібну структуру з вираженим смаком та ароматом), щэо дозволяє прискорити технологічний процес, розщирити асортимент, зменшити трудомісткість, поліпшити санітарно-гігієнічні умови, підвищити харчову цінність. На сучасному етапі розвитку винаходяться нові технології приготування даної страви з застосуванням інноваційних інгредієнтів. Представлено результати практичного обтрунтування технології молочного желе з порошком з бананів, що дозволяє підвищити якість страви та розширити асортимент продукції. В якості об'єктів дослідження було використано желе молочне як контрольний зразок; як дослід - желе молочне з використанням порочку з бананів. В об'єктах визначали органолептичні показники якості, титровану кислотність, щільність, масу сухих речовин за загальноприйнятими методиками. На першому етапі дослідження було виявлено, шо з підвищенням температури середовища для відновлення значення коефіиієнта водопоглинення збільшується, а також що відновлююча здатність води більша для даного порошку. Наступним етапом було вивчення впливу порошку з бананів на властивості желейної маси за допомогою додавання желатину, в результаті чого, було встановлено, що з підвищенням дозування порошку з бананів, тривалість застигання збільшується. На останньому етапі досліджень було встановлено рачіональне дозування порошку з бананів, яке забезпечує високі органолептичні властивості, такі як, виражений смак та аромат банану. Таким чином, зважаючи на те, шео отриманий зразок $\epsilon$ найближчим за фізико-хімічними показниками до натурального продукту, можсна зробити висновок, що використання порошків як з фруктів так і овочів, є перспективною та актуальною темою для подальших досліджень.

Ключові слова: желейна продукиія, желе молочне, порочок з бананів, пектинові речовини, технологічні прийоми, коефіцієнт відновлення, иукор, низькотемпературне сушіння, желатин, драглі.
\end{abstract}

\section{Исследование влияния порошка из бананов на показатели качества же- лейной продукции}

\author{
М.С. Черныш, А.В. Немирич \\ margarita.chernysh@gmail.com, avnemirich@mail.ru \\ Наииональный университет пищевых технологий, \\ ул. Владимирская, 68, г. Киев, 01601, Украина
}

\begin{abstract}
В статье проанализировано современное состояние производства и потребления десертов из желейной продукции и установлено, что наибольшей популярностью пользуются желе из натуральных ингредиентов без сахара. Наиболее популярныли они среди детей. Перспективным направлением обогащения желейной продукции является использование порошков (представляют собой мелкодисперсную порошкообразную структуру с выраженным вкусом и ароматом), что позволяет ускорить технологический процесс, расширить ассортимент, уменьшить трудоемкость, улучиить санитарногигиенические условия, повысить пищевую иенность. На современном этапе развития изобретаются новые технологии
\end{abstract}

\section{Citation:}

Chernysh, M.S., Niemirich, O.V. (2016). The research of influence of banana powder on jelly products. Scientific Messenger LNUVMBT named after S.Z. Gzhytskyj, 18, 2(68), 126-129. 
приготовления данного блюда с применением инновачионных ингредиентов. Представленные результаты практического обоснования технологии молочного желе с порошком из бананов позволяют повысить качество блюда и расширить ассортимент продукции. В качестве объектов исследования были использованы желе молочное как контрольный образец; как исследуемый - желе молочное с использованием порошка из бананов. В объектах определяли органолептические показатели качества, титруемая кислотность, плотность, массу сухих вещчеств по общепринятым методикам. На первом этапе исследования было обнаружено, что с повышением температуры среды восстановление значения коэффициента водопоглощения увеличивается, а также восстанавливающая способность воды больше для данного порошка. Следующим этапом было изучение влияния порошка из бананов на свойства желейной массы с помощью добавления желатина, в результате чего было установлено, что с повышением дозы порошка из бананов, продолжительность застывания увеличивается. На последнем этапе исследований было установлено рациональное дозирование порошка из бананов, которое обеспечивает высокие органолептические свойства, такие как, выраженный вкус и аромат банана. Таким образом, учитывая то, что полученный образец является ближайшим по физико-химическим показателям к натуральному продукту, можно сделать вывод, что использование порошков как из фруктов так и овощей, является перспективной и актуальной темой для дальнейших исследований.

Ключевые слова: желейная продукция, желе молочное, порошок из бананов, пектин, технологические приемь, коэффициент восстановления, сахар, низкотемпературная сушка, желатин, студни.

\title{
The research of influence of banana powder on jelly products
}

\author{
M.S. Chernysh, O.V. Niemirich \\ margarita.chernysh@gmail.com, avnemirich@mail.ru \\ National University of Food Technologies, \\ Volodymyrska Str., 68, Kyiv, 01601, Ukraine
}

The article analyzes the current state of the production and consumption of desserts, jelly products and found that the most popular are jelly made from natural ingredients with no sugar. The most popular among them children. A promising area of enrichment jelly products is the use of powders (powder are the fine structure with a distinct taste and aroma), which allows faster process, expand assortment, reduce labor intensity, improve hygiene conditions, increase the nutritional value. At the present stage of development of new technologies are invented preparation of dishes with innovative ingredients. These results substantiate the practical technology of milk jelly with banana powder can improve the quality and expand the range of food products. As objects of study jelly were used as a control sample of milk; like the study - milk jelly with banana powder. The object defines the organoleptic quality indicators, titratable acidity, density, mass of solids by conventional means. In the first stage of the study it was found that with an increase in ambient temperature recovery values of water absorption coefficient increases, as well as reducing power more water for the powder. The next step was to examine the effect of bananas on powder properties jelly mass by adding gelatin, whereby it was found that with increasing doses of powder from bananas, pour duration increases. At the last stage of studies have found a rational dosing of powder of bananas, which provides high organoleptic properties such as taste and flavor for a banana. Thus, given the fact that the resulting sample is the closest on the physical and chemical characteristics to the natural product, it can be concluded that the use of a powder of fruit and vegetables, is a promising and topical subject for further research.

Key words: jellies, milk jelly, banana powder, pectin, technology, the coefficient of restitution, sugar, low-temperature drying, gelatin, calves-foot.

\section{Вступ}

Здорове харчування -- це основа здоров'я людини. Їжа, що ми вживаємо, є джерелом енергії, яку організм витрачає у процесі своєї життєдіяльності. Саме вона дозволяє нашим клітинам і тканинам оновлюватися. І чим більш здорове харчування ви собі забезпечуєте, тим швидше оновлюється ваш організм і тим він стає молодшим. Ось чому здорове харчування $є$ таким важливим для кожної людини.

Желейна продукція користується попитом у закладах ресторанного господарства України, особливо серед дітей. Це пов'язано з високими смаковими властивостями, особливостями консистенції та інше. Проте дана продукція потребує підвищення харчової цінності, змінення текстури, розширення асортименту. Особливо актуальним є це в закладах ресторанного господарства типу бістро.

Науковцями в даному напрямку було проведено такі наукові дослідження з підвищення харчової цінності страв: Буртова 3.А. винайшла стійке желейне морозиво 3 використанням гомогенізації (Burtova et al., 2006); Боднарчук І.А. запропонував медове желе 3 імуномоделюючими властивостями, що включає використання водного відвару (1:30) липового цвіту, стабілізованого фруктовим пектином (Bodnarchuk et al., 2006).

Шудеговим С.В. розроблено технологію гранульованого солоного желе з проведенням забарвлення на етапі приготування розчину альгінату натрію (Shudegov and Shudegova, 2006); Салавеліс А.Д. вперше зробила кефірне желе з застосуванням хітозану (Salavelis et al., 2008); Татарченко C.I. представила слабоалкогольне желе, яке містить вуглекислоту (Tatarchenko, 2008).

Перспективним напрямком збагачення желейної продукції є використання порошків, зокрема порошку з бананів низькотемпературного сушіння. Це дозволяє прискорити технологічний процес, розширити асортимент, зменшити трудомісткість, поліпшити санітарно-гігієнічні умови, підвищити харчову цінність.

3 огляду на це, актуальним напрямком досліджень $\epsilon$ дослідження впливу порошку з бананів на якість желейної продукції, розроблення технології приготу- 
вання та адаптація іiї в закладах ресторанного господарства.

Метою статті було визначити вплив порошку з бананів для отримання желейної продукції найвищої якості.

Для досягнення поставленої мети сформульовано завдання статті:

- аналіз сучасного стану технології желейної продукції;

- дослідити регідратаційні властивості порошку 3 бананів;

- обгрунтувати рецептурний склад желейної продукції з додаванням порошку з бананів за органолептичними та фізико-хімічними показниками якості желе.

\section{Матеріал і методи досліджень}

В якості об'єктів дослідження було використано желе молочне (Zdobnov and Cyganenko, 2011) як контрольний зразок; як дослід - желе молочне з використанням порошку з бананів в дозуваннях 5, 10, 15\% до маси рецептурної композиції. В об'єктах визначали органолептичні показники якості, титровану кислотність, щільність, масу сухих речовин за загальноприйнятими методиками.

\section{Результати та їх обговорення}

Порошок з бананів низькотемпературного сушіння представляє собою дрібнодисперсну порошкоподібну структуру з вираженим смаком та ароматом бананів, кремового кольору (рис. 1).

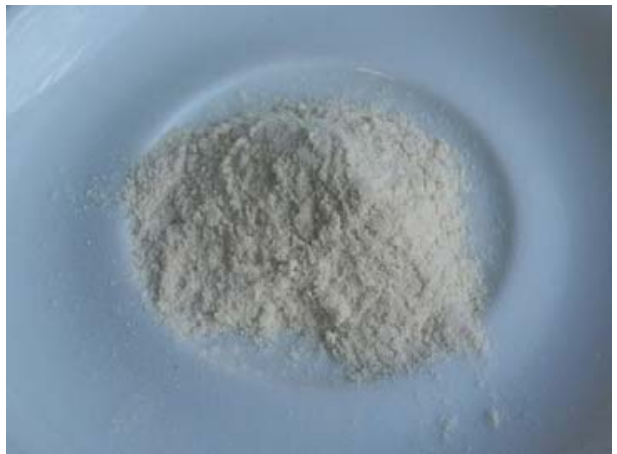

Рис.1. Порошок з бананів низькотемпературного сушіння

На першому етапі досліджень було визначено відновлюючу здатність порошку в молоці та воді в залежно від температури. Результати надані на рис. 2 та 3 відповідно. Дані відновлювачі було обрано з огляду на технологічні аспекти приготування желе молочного в закладах ресторанного господарства.

Як видно з рис. 2 та 3, 3 підвищенням температури середовища для відновлення значення коефіцієнта водопоглинання збільшується. Отримані данні обумовлюють технологічний прийом введення порошку до харчової системи, а саме: відновити у теплому молоці та з'єднати з желатином.
Наступним етапом було вивчення впливу порошку 3 бананів на властивості желейної маси, при цьому відновлений порошок додавали разом з розчиненим желатином до молока, визначали час застигання структури.

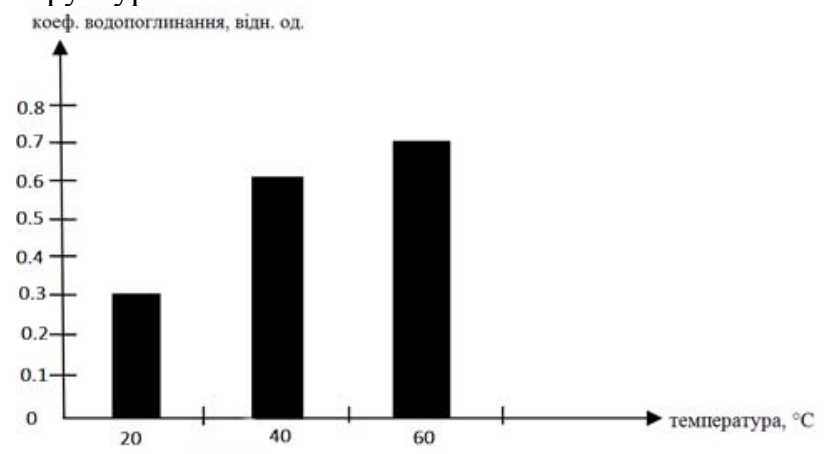

Рис. 2. Коефіціснт водопоглинання порошку 3 бананів залежно від температури води

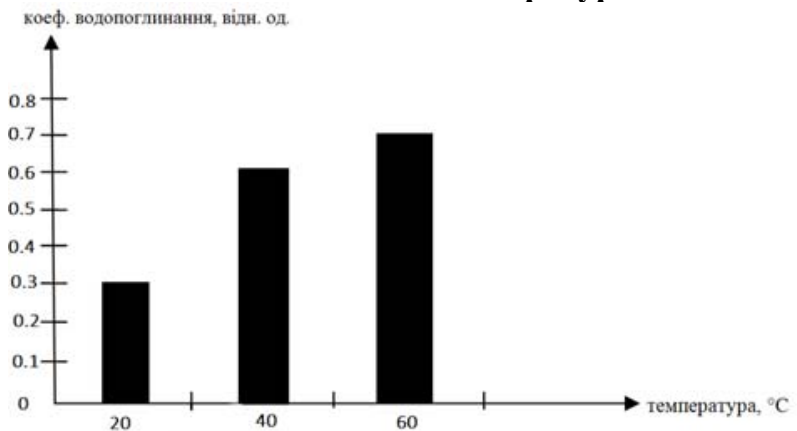

Рис. 3. Коефіціснт водопоглинання порошку 3 бананів залежно від температури молока

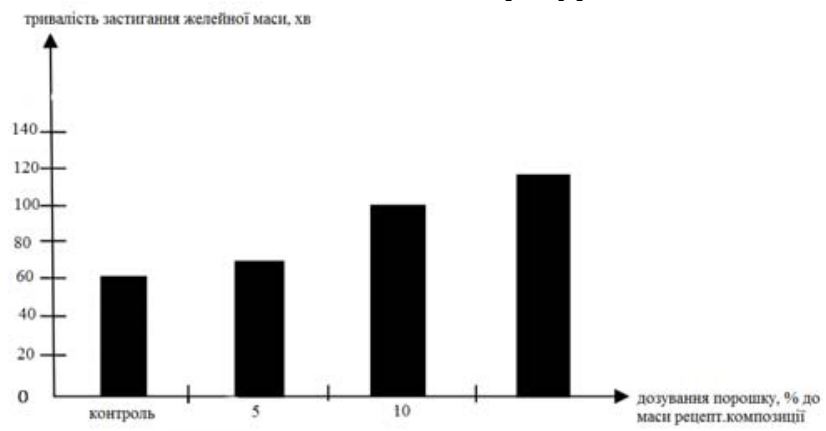

Рис. 4. Тривалість застигання желейної маси залежно від дозування порошку з бананів

Як видно з рис.4, 3 підвищенням дозування порошку з бананів, тривалість застигання збільшується. Це пов'язано з підвищенням міцності структури, де сухі речовини переважають в даній системі.

Досліджено вплив обраних дозувань порошку 3 бананів на органолептичні та фізико-хімічні показники якості желе молочного (табл. 1).

На підставі даних табл. 1 видно, що як раціональне дозування порошку з бананів можна обрати 10\%, оскільки воно забезпечує високі органолептичні властивості: виражений смак та аромат банану, вилучення 3 рецептури цукру за рахунок його достатньої концентрації в порошку з бананів. За фізико-хімічними показниками якості обраний зразок наближений за показниками до контрольного зразка. 
Вплив дозування порошку з бананів на органолептичні та фізико-хімічні показники якості желе молочного

\begin{tabular}{|c|c|c|c|c|}
\hline \multirow{2}{*}{ Показник } & \multicolumn{4}{|c|}{$\begin{array}{c}\text { Характеристика та значення в желе молочному з дозуванням порошку з бананів, \% до } \\
\text { маси рецептурної композиції }\end{array}$} \\
\hline & контроль & 5 & 10 & 15 \\
\hline Колір & $\begin{array}{l}\text { Маса білого ко- } \\
\text { льору }\end{array}$ & $\begin{array}{c}\text { Маса світло- } \\
\text { кремового кольору }\end{array}$ & $\begin{array}{l}\text { Маса кремового ко- } \\
\text { льору }\end{array}$ & $\begin{array}{l}\text { Маса насиченого } \\
\text { кремового кольору }\end{array}$ \\
\hline Запах & Молочний & $\begin{array}{l}\text { Легкий запах молока } \\
\text { з бананом }\end{array}$ & Запах банана & $\begin{array}{c}\text { Насичений бана- } \\
\text { новий аромат }\end{array}$ \\
\hline Смак & Молочний & Бананово-молочний & Банановий & $\begin{array}{l}\text { Насичений бана- } \\
\text { новий }\end{array}$ \\
\hline Консистенція & Однорідна маса & Однорідна маса & Однорідна маса & Неоднорідна маса \\
\hline 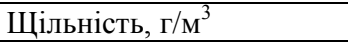 & 0,7 & 0,9 & 1,5 & 1,9 \\
\hline $\begin{array}{l}\text { Масова частка сухих } \\
\text { речовин, \% }\end{array}$ & 49 & 71,2 & 74 & 78 \\
\hline $\begin{array}{l}\text { Титрована кислотність, } \\
\text { град }\end{array}$ & 1,1 & 1,4 & 1,5 & 1,6 \\
\hline
\end{tabular}

\section{Висновки}

Досліджено коефіцієнт водопоглинання порошку з бананів залежно від температури води та молока. Показано, що 3 підвищенням температури середнє значення показника підвищується. Як раціональне обране дозування порошку з бананів $10 \%$ до маси рецептурної композиції, за органолептичними та фізико-хімічними показниками якості, а також впливом на структуру желе.

Перспективи подальших досліджень. Використання порошків як 3 фруктів так і овочів, є перспективною та актуальною темою, важною складовою якої $є$ визначення оптимальних концентрації у стравах та технологій застосування, що $є$ важливим етапом подальших досліджень.

\section{Бібліографічні посилання}

Burtova, Z.A., Illjashenko, T.I., Zvjaginceva, N.L. (2006). Pat. №12779 Sposib prygotuvannja zhelejnogo morozyva z pidvyshhenoju stijkistju do temperaturnyh vplyviv. A23G9/00. Publ. 15.02.2006. TOV «PRODSERVIS» (in Ukrainian).
Bodnarchuk, L.I., Maksjutina, N.P., Pashhenko, O.O., Musjalkovs'ka, A.O. (2006). Pat. №17415 Sposib otrymannja medovogo zhele «TILIA» $\mathrm{Z}$ imunomodeljujuchymy vlastyvostjamy. A23L1/076. Publ.15.09.2006. Nacional'nyj naukovyj centr «Instytut bdzhil'nyctva im.. P.I, Prokopovycha Ukrai'ns'koi' akademii' agrarnyh nauk» (in Ukrainian). Shudegov, Je.V., Shudegova, Je.Je. (2006). Pat. №17520 Sposib gotuvannja zhele granul'ovanogo solodkogo i solodkogo smaku. A23L1/328. Publ.15.09.2006 (in Ukrainian).

Salavelis, A.D., Gorkavenko, N.Je., Cherno, N.K., Ozolina, S.O., Kapustjan, A.I. (2008). Pat. №30416 Sposib vyrobnyctva kefirnogo zhele. A23L1/06. Publ. 25.02.2008. Odes'ka nacional'na akademija harchovyh tehnologij (in Ukrainian).

Tatarchenko, S.I. (2008). Pat. №30659 Slaboalkogol'nij zhelejnij produkt. A23L1/06. Publ. 11.03.2008 (in Russian).

Zdobnov, A.I., Cyganenko, V.A. (2011). Sbornik receptur bljud i kulinarnyh izdelij: dlja predprijatij obshhestvennogo pitanija. K.: Arij «Zhele molochnoe» (in Russian).

Стаття надійшла до редакції 26.09.2016 